\title{
BLENDED LEARNING AND USER SATISFACTION
}

\author{
Hillary N. Mellema, Central Michigan University, melle1hn@cmich.edu \\ Karl L. Smart, Central Michigan University, karl.smart@ cmich.edu \\ Christine M. Shull, Central Michigan University, shull1cm@cmich.edu \\ Michelle Salmona, Central Michigan University, michelle.salmona@cmich.edu
}

\begin{abstract}
Increasingly, e-learning is gaining popularity and acceptance both in academic as well as in corporate environments. With the rapid increase of online instruction, many experts predict that e-learning may at some point become the largest source of higher education. A significant factor related to the acceptance and success of e-learning involves students' perceptions of and attitude towards online learning. In addition, past experiences with actual online instruction can be an important factor in students' perceptions of e-learning. This study surveys students' experience with an online unit in a traditional face-to-face course. Included also are student evaluations of several online components of a web-based course management software used in the course. Additional research can provide greater insight into the factors that promote the acceptance of and success with online instruction.
\end{abstract}

Keywords: Blended learning, E-learning, student perceptions, online components

\section{INTRODUCTION}

E-learning is gaining popularity because it meets the challenges of time, distance, and availability related to education and higher learning. Despite all of its merits, traditional classroom instruction is limited in space, time, and pace [1]. In contrast, many of the initial arguments against distance learning are being resolved. Online learning is becoming more activityfocused and application-based. This trend has distinct advantages over traditional methods of lecture and assessment. E-learning is also a cost-effective solution allowing universities to capture continuing education markets for engineers, doctors, and teaching professionals. Online learning appeals to students who have limited time to travel to and stay at the university campus [1]. Because of available technology, online learning has become interactive and has the potential to create active learning environments where students learn by doing as they build new knowledge. This active approach to learning focuses beyond content and curriculum and emphasizes complex thinking and problem solving. $[18,22,25]$.

To facilitate the appropriate growth of e-learning, it is important to evaluate the experience and challenges students encounter with online instruction. This preliminary study assesses how user satisfaction is affected by user experience in two undergraduate business courses taught with a blend of online and traditional approaches. The focus of this study involves student perceptions of online learning and how the perceptions of students differ based upon a number of limited variables. Variables which affect satisfaction may include - but are not limited toease of use, previous experience with online learning units, computer experience, number of years in school, and amount of time available to dedicate to online learning. Although the future growth of elearning is assured, educators must remember that some students still prefer the traditional study environment to the less personal nature of online learning units [1].

\section{LITERATURE REVIEW}

The term "distance learning" is used to describe formal instruction which takes place when teachers and learners are not in the same location [13, 19]. Elearning is considered to be a subset of distance learning and is often used to describe technologybased learning [21]. For the purpose of this paper, the term "e-learning" will be defined as the delivery of instructional material using electronic media [21]. In the past, traditional learning methods have been limited in scope, and the demand for the flexibility which e-learning provides continues to grow $[1,19]$. Recent progress in collaborative technology has combined e-learning or web-based instruction with traditional distance learning approaches $[7,19,24$, 25]; Ward \& LaBranche, 2003 
Koohang and Durante (2003) surveyed students in an effort to measure the perceptions of learners while they completed web-based instructional delivery activities. They found that experience with the Internet was a significant factor in a user's perception toward web-based learning. Similarly, Gefen and Karahanna's (2003) study tracking users of Internet vendors concluded that repeat customers had a higher level of trust in the vendor and "perceived the website to be more useful and easier to use, and were more inclined to purchase from it" ( $p .111)$. This research suggests that previous experience involving technology affects a user's satisfaction related to use of the site. Results of a study by Stoel and Lee, creators of the Technology Acceptance Model, revealed that as students increase their level of experience with a technology, they find that technology easier to use and students are more likely to use the program in the future (2003). Studies have found that repeat users find websites more useful and easier to use $[12,17,25,26,28]$ and that "computer users' prior experience with technology affects their attitudes about technology in general" [25, p. 213]. A case study by Henry \& Stone found that a users' experience level with computers directly affects their sense of computer abilities and outcome expectations. The case also found that if users find the system to be of low quality or difficult to use, they will reject the system [17].

\section{METHODOLOGY}

The purpose of this study was to assess students' responses to integrating and blending online learning components into a traditional face-to-face course. Students from two courses at a medium-sized Midwestern university completed surveys at the end of their courses regarding their experience with the course. The course was offered in a traditional format; however, online components were utilized using a popular course management software (Blackboard). The course also included online quizzes over required reading material, discussion postings on an asynchronous discussion board, and postings of course assignments, activities, resources, and grades. Additionally, two completely online units were integrated into the class course which students completed outside of class. The units focused on the content students needed to know to pass a state certification exam. The exam was independent of the course and the focus was added to increase student competency on that exam.

Students used the course management software throughout the semester. The majority of readings connected with the course were posted electronically, and three content quizzes were given over required readings the first half of the semester. Students were also required to contribute weekly online postings in asynchronous threaded discussions. The semester concluded with two online units that included readings, interactive exercises and applications, and content assessments. In order to receive credit for the online assignments, students needed to achieve 90 percent accuracy. Although the courses were run in a traditional face-to-face format, significant portions of the class were handled through online activities; creating a blended approach to the content. Past research studies have indicated that acceptance of elearning involves both the students' perceptions and their past experience with actual online instruction. This study blended the familiar approach of the traditional classroom with online instructional units and course management software. The data for the study are based on a survey which was administered at the end of the courses. The survey instrument, designed to collect information about the course participant's perceptions of the online portion of the blended learning course, was made available to the learners following course completion. The survey contained 13 questions: 12 of which were answered using a Likert scale and 1 question was open-ended. This allowed students an opportunity to express ideas which were not addressed in the questionnaire. The 12 statements using a Likert scale recorded levels of satisfaction with the online learning units. Six of the responses were recorded so that strongly agree $=5$, moderately agree $=4$, undecided $=3$, moderately disagree $=2$, and strongly disagree $=1$ Six additional items were selected for evaluation using the following Likert scale: 5=strongly satisfied, $4=$ moderately satisfied, $3=$ undecided, $2=$ moderately dissatisfied, $1=$ strongly dissatisfied.

\section{RESULTS}

The findings from the survey reflect students' attitudes towards the online components of the course. Most of the evaluation measures focus on subjects' satisfaction with online units. Overall, 3 students (8 percent) claimed they were extremely satisfied with the online units. Eighteen participants (50 percent) were moderately satisfied and 14 (39 percent) were neither dissatisfied nor satisfied. Only 1 participant was moderately dissatisfied while no students were extremely dissatisfied. An analysis of the effect of gender on the difference in the overall satisfaction level with the online units found that female students appear to be more satisfied with the units, but the difference is not significant at a .05 level (see Table 1). Overall satisfaction was affected by the respondent's year in school. The $4^{\text {th }}$ year 
students appear to be more satisfied with the online units they completed, and the satisfaction scores of $3^{\text {rd }}$ year and $4^{\text {th }}$ year students are significantly different, as shown in Table 2.

Table 1. Group Statistics: Gender

\begin{tabular}{|l|l|l|l|l|}
\hline $\begin{array}{c}\text { Satisfaction with } \\
\text { units based on } \\
\text { Gender }\end{array}$ & $\mathrm{N}$ & Mean & $\begin{array}{c}\text { Std. } \\
\text { Deviation }\end{array}$ & $\begin{array}{c}\text { Std. Error } \\
\text { Mean }\end{array}$ \\
\hline 1 & 13 & 3.38 & .650 & .180 \\
2 & 25 & 3.80 & .645 & .129 \\
\hline
\end{tabular}

Table 2. Group Statistics: Year in School

\begin{tabular}{|l|l|l|l|l|}
\hline \multicolumn{1}{|l|}{ Year } & $\mathrm{N}$ & Mean & $\begin{array}{c}\text { Std. } \\
\text { Deviation }\end{array}$ & $\begin{array}{c}\text { Std. Error } \\
\text { Mean }\end{array}$ \\
\hline 3 & 2 & 3.00 & .000 & .000 \\
4 & 36 & 3.69 & .668 & .111 \\
\hline
\end{tabular}

The level of computer experience related to overall level of satisfaction with the online units appears to be positively related although the relationship between them is not statistically significant (Table 3 ). From the analysis there are positive correlations between satisfaction with the discussion board, the posting of resources (websites and links) and other course-related information as well as the use of online quizzes or assessments. Overall, students were satisfied with the online units they completed.

Table 3. Correlations: Experience and Satisfaction

\begin{tabular}{|ll|l|l|}
\hline & & $\begin{array}{l}\text { Satisfaction } \\
\text { with Units }\end{array}$ & $\begin{array}{l}\text { Computer } \\
\text { Experience }\end{array}$ \\
\hline $\begin{array}{l}\text { Satisfaction } \\
\text { with Units }\end{array}$ & Pearson Correlation & 1.000 & .285 \\
& Sig. (2-tailed) & & .083 \\
\hline $\begin{array}{l}\text { Computer } \\
\text { Experience }\end{array}$ & Pearson Correlation & .285 & 1.000 \\
& Sig. (2-tailed) & .083 & \\
& $\mathrm{~N}$ & 38 & 38.000 \\
\hline
\end{tabular}

The results of the satisfaction ratings from the course are shown in Table 3. The majority of the respondents (44 percent moderate and 39 percent strongly) were satisfied with the use of discussion board and questions related to the course material. Eighty-two percent of the students (26 percent moderately and 55 percent strongly) were satisfied with the instructor's use of online quizzes and assessments. Eighty-nine percent (42 percent moderately and 47 percent strongly) were satisfied with the course's use of Blackboard to supplement traditional learning methods.

Table 4. Satisfaction Ratings

\begin{tabular}{|c|c|c|c|}
\hline & $A^{*}$ & $\mathrm{~B}^{* *}$ & $\mathrm{C}^{* * *}$ \\
\hline 1(Strongly Dissatisfied) & $3 \%$ & $5 \%$ & $0 \%$ \\
\hline 2 (Moderately Dissatisfied) & $6 \%$ & $0 \%$ & $3 \%$ \\
\hline 3 (Undecided) & $8 \%$ & $13 \%$ & $8 \%$ \\
\hline 4 (Moderately Satisfied) & $44 \%$ & $26 \%$ & $42 \%$ \\
\hline 5 (Strongly Satisfied) & $39 \%$ & $55 \%$ & $47 \%$ \\
\hline
\end{tabular}

\section{PERCEIVED BENEFITS AND WEAKNESSES OF THE ONLINE UNITS}

Participants were given the opportunity to share open-ended responses and comment on the strengths and weaknesses of the online learning units, as shown in Table 5. Students' responses showed that they valued the web-based instruction because important concepts in the course were emphasized, and students enjoyed working at their own pace.

Table 5. Perceived Strengths and Problems/Limitations of the Online Learning Units

\begin{tabular}{|lc|}
\multicolumn{1}{|c}{$\begin{array}{c}\text { Perceived Strengths of } \\
\text { Online Learning Units }\end{array}$} & $\begin{array}{c}\text { No. of users } \\
\text { mentioning * }\end{array}$ \\
$\begin{array}{l}\text { Content: units used to reinforce } \\
\text { important concepts } \\
\text { Flexibility: convenience, ability } \\
\text { to complete at own pace }\end{array}$ & 7 \\
$\begin{array}{l}\text { Gained valuable experience } \\
\text { learning in an online } \\
\text { environment }\end{array}$ & 11 \\
$\quad \begin{array}{l}\text { Perceived Weaknesses of } \\
\text { Online Learning Units }\end{array}$ & $\begin{array}{c}\text { No. of users } \\
\text { mentioning* }\end{array}$ \\
Intangibility of online units & 4 \\
Lack of social aspect & 2 \\
Internet trouble & 1 \\
\hline
\end{tabular}


The open-ended responses in Table 5 cite more strengths than weaknesses. Most of the students believed that they gained valuable experience learning in an online environment, and felt that they could integrate the technology into future situations. Some students still prefer the social interaction and tangible nature of a classroom over online learning. The students also realized that there was a link between how they were learning the material online and their future careers. One student commented "I think that online learning is essential in business courses because so much is done by use of the Internet in the real world." Another said "Students should learn how to use it so they are comfortable using it in their future lives." As reported earlier, the students also liked the flexibility of being able to work within their own time-frame and to review the work at their own pace, "I like online learning. It is a different way to learn about topics. It allows you to work at your own pace ... it was nice to have ample time to read and work on the quizzes."

Some of the students had difficulty with the online format of the learning units. One student had difficulty contacting the instructor for clarification; another would have liked better directions; and one cited frustration from Internet trouble. Four students found a problem with the social isolation of the online environment. However, these criticisms were outnumbered by favorable responses from the participants. There were only 8 negative freeresponses out of the 39 survey respondents.

\section{CONCLUSIONS}

This study provides insights about students' satisfaction of, attitudes towards, and experiences with online components integrated into a traditional face-to-face course. This study revealed that students overall were satisfied with the online learning units in the course.. The results indicate that gender is not significantly related to user satisfaction but that the participants' year in school is significantly related to user satisfaction. Although literature suggests that computer users' prior experience with technology affects users' satisfaction with technology, this study did not find a statistically significant relationship between the two. The study also found there were positive correlations between satisfaction with the discussion board, the posting of resources (Web sites and links) and other course-related information and the use of online quizzes or assessments with overall satisfaction with the online units completed. If the students are satisfied with one element of online learning, they will likely be satisfied with other online elements of learning.

The study reveals a number of valuable insights. Students recognized the relevance of using technology and learning online. They know such skills are of growing importance in today's world as captured in the following statements on the survey: "Technology is expanding everyday so we must learn how to adapt to learning information from computers. I believe that the online learning was very valuable and should be done in the future.", "Though the internet is almost vital in this day in age, for most there is still much to learn about it. The combination of the internet and learning is helpful and makes learning more interesting." The scope of this study was limited and preliminary in nature. Additional areas should be explored; for instance, although students were asked to rate their proficiency in computer usage, they were not asked whether they had taken an online course or online components in a course before. Having been involved in an actual elearning experience is probably a better predictor of attitudes and perceptions than mere computer experience. Other research exploring how students react to online learning in various content areas would also prove useful in determining how best to implement e-learning. With the growing trend toward e-learning, little doubt exists that online instruction will continue to become significant in academic and corporate settings. This and additional research can explore how students perceive and use online learning, finding ways to better engage students and help them master both content and problem solving skills needed in a competitive global workplace.

\section{REFERENCES}

1. Beller, M. \& Or, E. (1998). The crossroads between lifelong learning and information technology: A challenge facing leading universities. Journal of Computer-Mediated Communication (online journal), 4(2) (December). Retrieved 31 March, 2009 from http://jcmc.indiana.edu/vol4/issue2/beller.html

2. Benbunan-Finch, R. \& Starr, R. H. (2003). Mediators of the effectiveness of online courses. IEEE Transactions on Professional Communication, 46(4), 296-312.

3. Benek-Rivera, J., \& Matthews, V.E. (2004). Active learning with jeopardy: Students ask the questions. Journal of Management Education, 28, 104-118.

4. Bonwell, C. C., \& Eisen, J. A. (1991). Active learning: Creating excitement in the classroom 
(ASHE-ERIC Higher Education Report No. 1). Washington, DC: George Washington University.

5. Bransford, J. D., Brown, A. L., \& Cocking, R. R. (Eds.). (2000) How people learn: Brain, mind experience, and school committee on developments in the science of learning. Commission on Behavioral and Social Sciences and Education of the National Research Council, National Academy Press.

6. Brass, K. (2002). Pushing E-learning. Sales and Marketing Managemen, 154(3), 56.

7. Davis, J. (2000). Traditional vs. online learning: It's not an either/or proposition. Employment Relations Today, 27(1), 47-60.

8. Driscoll, M. (2002) How people learn (and what technology might have to do with it). ERIC Clearinghouse on Information and Technology Syracuse, NY. Retrieved 31 March, 2009 from http://www.ericdigests.org/2003-3/learn.htm

9. Driscoll, M \&Carliner, S. (2005). Advanced webbased training strategies. San Francisco: Pfeiffer.

10. E-learning replaces classroom. (2003). Health Management Technology, 24(4), 52-60.

11. Frankola, K. (2001). Why online learners drop out. Workforce, 10, 52-60.

12. Gefen, D., Karahanna, E. \& Straub, D. W. (2003). Inexperience and experience with online stores: The importance of TAM and trust. IEEE Transaction on Engineering Management, 50(3), 307-321.

13. Gilbert, S. W. (1995). Why distance education? A special bulletin. American Association for Higher Education, 48.

14. Golladay, R., Prybutok, V. \& Huff, R. (2000). Critical success factors for the online learner. Journal of Computer Information Systems, 40(4), 69-71.

15. Hara, N. \& Kling, R. (2000). Students' distress with a web-based distance education course: An ethnographic study of participants' experiences. Information, Communication and Society, 3(4), 557-579.

16. Haugen, S., LaBarre, J., \& Melrose, J. (2001) Online course delivery: Issues and challenges. Issues in Information Systems, 2, 127-131.

17. Henry, J. W. \& Stone, R. W. (1994). A structural equation model of end-user satisfaction with a computer-based medical information system. Information Resources Management Journal, 7(3), 21-34.

18. Johnston, J., Killion, J., \& Oomen, J. (2005). Student satisfaction in the virtual classroom. The Internet Journal of Allied Health Sciences and Practice. 3. Retrieved 31 March, 2009 from http://ijahsp.nova.edu/articles/vol3num2/johnsto $\underline{\text { n.pdf }}$

19. Koohang, A. \& Durante, A. (2003). Learners' perceptions toward the web-based distance learning activities/assignments portion of an undergraduate hybrid instructional model. Journal of Informational Technology Education 2, 105-113. Retrieved 22 April, 2009 from http://jite.org/documents/Vol2/v2p105-11378.pdf

20. Koprowski, G. (2000). Online learning: The competitive edge. Informationweek (August 28), 124-128.

21. Meyen, E. L., Aust, R., Gauch, J. M., Hinton, H. S., Isaacson, R. E., Smith, S. J., Tee, M. W. (2002) e-learning: A programmatic research construct for the future. Journal of Special Education Technology. Retreived March 22, 2009, from http://jset.unlv.edu/17.3/smith/smith.pdf

22. Pallof, R., \& Pratt, K. (2003). The virtual student: A profile and guide to working with online learners. San Francisco, CA: Josey-Bass Publishers.

23. Ryan, S. (2001) Is online learning right for you? American Agent \& Broker, 73(6), 54-58.

24. Sarason, Y. \& Banbury, C. (2004) Active learning facilitated by using a game-show format or who doesn't. Journal of Management Education, 28(4), 509-518.

25. Smart, K.L., Cappel, J.J. (2006). "Students' perceptions of online learning: a comparative study", Journal of Information Technology Education, Vol. 5 pp.201-19.

26. Stoel, L. \& Lee, K. H. (2003). Modeling the effect of experience on student acceptance of Web-based courseware. Internet Research, 13(5), 364-374.

27. Watkins, R. (2005). Developing interactive elearning activities. Performance Improvement, 44, 5-7.

28. Wober, K. \& Gretzel, U. (2000). Tourism managers' adoption of marketing decision support systems. Journal of Travel Research, 39(2), 172-182. 